\title{
Chemical diversity of the volatiles of Lippia rotundifolia Cham. (Verbenaceae) in Minas Gerais, Brazil
}

\author{
MESSULAN R. MEIRA, ERNANE R. MARTINS AND FRANCINE S.A. DA FONSECA \\ Instituto de Ciências Agrárias da Universidade Federal de Minas Gerais, Av. Universitária, \\ 1000, Bairro Universitário, 39404-547 Montes Claros, MG, Brazil \\ Manuscript received on May 18, 2018; accepted for publication on June 27, 2018
}

\begin{abstract}
How to cite: MEIRA MR, MARTINS ER AND FONSECA FSA. 2019. Chemical diversity of the volatiles of Lippia rotundifolia Cham. (Verbenaceae) in Minas Gerais, brazil. An Acad Bras Cienc 91: e20180498. DOI DOI.

Abstract: Lippia rotundifolia is an aromatic species, native and endemic to rocky fields, which are isolated by small mountains. It is little known about their chemical composition. Because of that we aimed to study the chemical diversity of volatiles released from rosemary leaves (Lippia rotundifolia Cham.) coming from 11 populations of the Minas Gerais, Brazil. The material for chemical analysis was obtained from the accessions in the active germplasm bank of the Instituto de Ciências agrárias of the Universidade Federal de Minas Gerais. A total of 67 compounds were detected by HS-CG-MS. Most volatiles were detected in the São Gonçalo do Rio das Pedras accession, with 40 compounds, whereas in the Santana do Riacho accession only 5 compounds were detected. Volatiles myrcene, linalool and caryophyllene were detected in the majority of the accessions. We concluded that Lippia rotundifolia presents high chemical variability. The volatiles mircene, linalool and caryophyllene are the most frequent, detected in most of the accessions. Due to some accession to present predominance of monoterpenes, others sesquiterpenes, studies of molecular analysis are necessary for associate the chemotypes, since environmental variation influence the gene expression of the secondary metabolites.
\end{abstract}

Key words: chemical variability, medicinal plant, rosemary, static headspace.

\section{INTRODUCTION}

The Cerrado concentrates one of the highest endemism rates of Brazilian flora. With approximately $30 \%$ of the local vegetation intact, it is considered one of the conservation hotspots (Gastauer et al. 2012). In Minas Gerais these environments are located in rupestrian fields, one of the phytophysiognomies of the Brazilian Cerrado. The rupestrian fields are characterized by altitudes

Correspondence to: Messulan Rodrigues Meira

E-mail: messulan.meira@gmail.com

ORCid: https://orcid.org/0000-0003-2447-342X above $800 \mathrm{~m}$, xeromorphism and presence of rocky outcrops (Rapini et al. 2008).

In the floristic composition of this phytophysiognomy, there is a predominance of species of the Verbenaceae family (Carvalho et al. 2012). The genus Lippia Linn. is the second largest in this family, where most endemic species are concentrated at these altitudes (Fernandes et al. 2011, Jacobi et al. 2011, Carvalho et al. 2012). Among the endemic species of rupestrian fields is Lippia rotundifolia Cham. Popularly known as pedestrian tea and rosemary, it is a shrub from 0.5 to $2 \mathrm{~m}$ tall (Salimena and Silva 2009), in restricted 
populations with few individuals (Martens 2008). Its flowers are grouped in large bunches ranging from pink-lilac to magenta or false pink (Salimena and Silva 2009).

In the natural environment Lippia rotundifolia is confused with others of the same genus due to the great morphological similarity and reproductive synchronism, making it difficult to botanical identification and collect of plant material. For this reason, chemical composition analysis studies of native species are scarce (Salimena and Mulgura 2015).

This plant is aromatic and produces volatile compounds, as a product of the secondary metabolism, which are released by the leaves and flowers. Studies of essential oils report mircene $(22.3 \%)$, limonene (26\%) as majorities (Leitão 2008). The hydrodistillation method to obtaining the chemical compounds is the most common and widely used method (Council of Europe 2010). The volatile fraction, the emitted fragrance, is established by the equilibrium between the plant and its vapor phase, but there is no record of volatile fraction studies for this species. The headspace method of extracting volatiles is the most appropriate for studies of these fragrances, since this method allows to obtain the composition of the genuine odor of the plant (Stashenko et al. 2002).

Therefore the knowledge of the chemical profile starting from the study of the volatile compounds of this species is important to the systematic and botanical contribution. In addition to distinguishing chemotypes of commercial interest that deserve to be maintained in the natural environment, aiming at the conservation of their existing genetic resources (Stashenko et al. 2002). Due to endemism and aromatic potential of the species, the aim of this research was to study the chemical diversity of volatiles released from rosemary leaves (Lippia rotundifolia Cham.) coming from 11 populations of the Minas Gerais, Brazil.

\section{MATERIALS AND METHODS}

\section{SAMPLES ACQUISITION}

Samples of Lippia rotundifolia were collected in 11 naturally occurring populations in the state of Minas Gerais. The specimens were identified by Dr. Rúbia Santos Fonseca and deposited in the EPAMIG herbarium. The propagation material was grown in conditions of the greenhouse of the Institute of Agrarian Sciences of the Federal University of Minas Gerais (ICA / UFMG). The location and climatic characteristics of each accession are presented in Table I.

The samples were taken from the apical meristem and leaf primordia of individuals from each place of species occurrence at 7:00 $\mathrm{h}$ in the morning. Approximately $1.5 \mathrm{~g}$ were weighed on an analytical balance and were transferred to $20 \mathrm{~mL}$ vials where were kept for 1 hour in a freezer at -20 $\circ$. Subsequently, the identified fresh material was sealed with silicone septum / PTFE and transported to the Analytical Chemistry Laboratory of the ICA / UFMG.

\section{EXTRACTION OF VOLATILES AND CHROMATOGRAPHIC ANALYSIS VIA STATIC HEADSPACE (HS CG-EM)}

The volatiles extraction was through static headspace using an automatic sampler system (HS Combi-PAL). Each sample was homogenized at $500 \mathrm{rpm}$ and incubated at $75{ }^{\circ} \mathrm{C}$ for 5 minutes and immediately analyzed by HS-CG-MS. After this period, a $1000 \mu \mathrm{L}$ volume of the sample in steam phase was injected in splitless mode with a gastight $2.5 \mathrm{~mL}-\mathrm{HS}$ syringe. The injection rate was 500 $\mu \mathrm{L} / \mathrm{s}$ at $220^{\circ} \mathrm{C}$.

Analyzes were performed on an Agilent ${ }^{\circledR}$ 7890A gas chromatograph coupled to an Agilent ${ }^{\circledR}$ MSD 5975C mass spectrometer (Agilent Technologies, California, USA). A DB-5 MS fused silica capillary column (Agilent Technologies, California, USA) with stationary phase of $5 \%$ 
TABLE I

Location of eleven naturally occurring populations of Lippia rotundifolia in Minas Gerais, Brazil.

\begin{tabular}{|c|c|c|c|c|c|c|}
\hline \multirow{2}{*}{ Code City } & \multicolumn{2}{|c|}{ Coordinates } & \multicolumn{3}{|c|}{ Climate conditions } & \multirow{2}{*}{ Herbal depo } \\
\hline & Latitude & Longitude & $\begin{array}{l}\text { Alt. } \\
\text { (m) }\end{array}$ & $\begin{array}{c}\text { Precip. } \\
\text { (mm) }\end{array}$ & $\begin{array}{c}\text { Temp. } \\
\left(C^{\circ}\right)\end{array}$ & \\
\hline PVP - Cônego Marinho & $-14^{\circ} 55^{\prime} \mathrm{S}$ & $-44^{\circ} 38^{\prime} \mathrm{W}$ & 729 & 700 & $23 \pm 1$ & PAMG 58090 \\
\hline SNO - Rio Pardo de Minas & $-15^{\circ} 36^{\prime} \mathrm{S}$ & $-42^{\circ} 44^{\prime} \mathrm{W}$ & 790 & 700 & $20 \pm 1$ & PAMG 58096 \\
\hline ABO - Montes Claros & $-16^{\circ} 56^{\prime} \mathrm{S}$ & $-43^{\circ} 55^{\prime} \mathrm{W}$ & 700 & 1100 & $22.5 \pm 1$ & PAMG 58101 \\
\hline GIG - Botumirim & $-16^{\circ} 35^{\prime} \mathrm{S}$ & $-42^{\circ} 55^{\prime} \mathrm{W}$ & 726 & 1350 & $22.5 \pm 2$ & PAMG 58097 \\
\hline RPE - Botumirim & $-16^{\circ} 52^{\prime} \mathrm{S}$ & $-43^{\circ} 28^{\prime} \mathrm{W}$ & 722 & 1100 & $22.5 \pm 2$ & PAMG 58094 \\
\hline ODA - Olhos D’água & $-17^{\circ} 26^{\prime} \mathrm{S}$ & $-43^{\circ} 37^{\prime} \mathrm{W}$ & 691 & 1100 & $22.5 \pm 2$ & PAMG 58094 \\
\hline JFE - Joaquim Felício & $-17^{\circ} 44^{\prime} \mathrm{S}$ & $-44^{\circ} 11^{\prime} \mathrm{W}$ & 1010 & 1350 & $22.5 \pm 3$ & PAMG58093 \\
\hline PRP - São Gonçalo do Rio Preto & $-18^{\circ} 06^{\prime} \mathrm{S}$ & $-43^{\circ} 20^{\prime} \mathrm{W}$ & 901 & 1350 & $<19$ & PAMG 58091 \\
\hline SGS - Serro & $-18^{\circ} 25^{\prime} \mathrm{S}$ & $-43^{\circ} 28^{\prime} \mathrm{W}$ & 1020 & 1350 & $18 \pm 2$ & PAMG 58100 \\
\hline RTI - Gouveia & $-18^{\circ} 33^{\prime} \mathrm{S}$ & $-43^{\circ} 49^{\prime} \mathrm{W}$ & 1020 & 1350 & $20 \pm 2$ & PAMG 58092 \\
\hline SRI - Lapinha & $-19^{\circ} 16^{\prime} \mathrm{S}$ & $-43^{\circ} 37^{\prime} \mathrm{W}$ & 756 & $>1500$ & $20 \pm 2$ & PAMG 58099 \\
\hline
\end{tabular}

SNO: Serra Nova State Park; PVP: Veredas do Peruaçu State Park; ABO: Abóboras Community; GIG: Gigante Community; RPE: Margins of the Rio do Peixe; ODA: APA de Olhos d'água; JFE: Private Property in Joaquim Felício; PRP: Rio Preto State Park; SGS: São Gonçalo do Rio das Pedras; RTI: Stream of Rio Tigre; SRI: Santana do Riacho. Alt.: Altitude in meters; Precip.: Average annual precipitation in millimeters; Temp.: Average annual temperature in degrees.

phenyl and 95\% polymethylsiloxane (30 m length x $250 \mu \mathrm{m}$ internal diameter x $0.25 \mu \mathrm{m}$ internal film thickness) (California, USA). Helium (99.9995 $\%$ purity) was used as drag gas with flow of 1 $\mathrm{mL} \cdot \mathrm{min}^{-1}$.

The heating ramp started at $35^{\circ} \mathrm{C}$, maintaining it in an isothermal condition for $2 \mathrm{~min}$, increasing at $3{ }^{\circ} \mathrm{C} \cdot \mathrm{min}^{-1}$ to $150^{\circ} \mathrm{C}$, holding for $10 \mathrm{~min}$ and ending at $300{ }^{\circ} \mathrm{C}$ for one minute. Injector and transfer line temperatures for MS were maintained at $220{ }^{\circ} \mathrm{C}$ and $240{ }^{\circ} \mathrm{C}$, respectively. The mass spectrometer was operated by electron impact ionization (70 $\mathrm{eV}$ ), in a range of $35-550 \mathrm{~m} / \mathrm{z}$.

The concentrations of the constituents of the chemical analysis were expressed by the percentage of relative area of the total chromatogram ions \pm standard deviation $(n=3)$. The identification of each constituent was by comparison of their retention times relative to the co- determination of a hydrocarbon standard solution (C8-C20, SigmaAldrich ${ }^{\circledR}$, St. Louis, USA) and by comparison of the mass spectra of the (NIST/EPA/NHI (Nist
2008) library database and literature. The retention indices were calculated using the equation proposed by Van Den Dool and Kratz (1963).

\section{MULTIVARIATE STATISTICAL ANALYSIS}

The Cluster analysis was performed using the closest neighbor pairing methods (UPGMA). For this analysis, the data were arranged in a binary matrix of presence and absence of the identified volatiles. This grouping was based on the Jaccard (j) similarity coefficient and the Euclidean distance between the compounds, adopting SAHN (Sequential Agglomeration Hierarchy and Nested Clustering). For greater efficiency in the results, the data were submitted to the Pearson correlation analysis ( $\mathrm{r})(\mathrm{P} \leq 0.5)$, and were also autoscaled to verify if had the minimum correlation to justify its use in the data matrix as well as to avoid the effects produced by the variable size. Following conducted to principal component analysis (PCA). The retention of PCA axes to be interpreted was obtained by reducing the set of in linear combinations, 
which generated scores identification of the most relevant chemical compounds in the discrimination of the different sites of occurrence. All statistical analysis were performed with the help of the Ntsys PC program. 2.11 (Rohlf 2000).

\section{RESULTS AND DISCUSSION}

In the chemical analysis by the HS-GC-MS method, 67 peaks were detected and of these 57 were identified. The percentages of volatiles are expressed in relative area of the peak for each analyte in Table II. The number of compounds identified were higher than the reported by Gomide et al. (2013) that identified 24 compounds in leaves and lower than the reported by Leitão (2008) that identified 108 compounds in leaves and 54 in flowers. Of the compounds identified by the latter author, 18 were identified in the present study. The chemical composition of the volatiles of the plant was quite varied, both in composition and in percentage, from one place to another. As for chemical classes in five populations (GIG, RPE, RTI, SGS, PRP), there was a predominance of monoterpenes, ranging from $42.4 \%$ in the RPE to $61 \%$ in RTI. In the other six populations (JFE, ABO, SRI, SNO, ODA, PVP), there was a predominance of sesquiterpenes, with $43.7 \%$ in $\mathrm{ABO}$ and $65.5 \%$ in JFE, respectively (Table II). This percentage was higher than that in the results obtained in previous studies with essential oils for the same species, in which the monoterpenes were predominant, with $52.5 \%$, even considering the loss of the most volatile fraction by the method (Leitão 2008).

The chemical compounds identified were well distributed among the individuals analyzed for the 11 environments. The chemical composition varied both in the number of volatile compounds as well as in the percentage of relative area of the total chromatogram of each accession. The results showed that the accession are heterogeneous in relation to the production of these volatiles. Of the 67 compounds detected, ten stood out regarding higher production. The most important compounds were $\alpha$-pinene, myrcene, $\alpha$-phellandrene, limonene, linalool, tagetone, $\beta$-elemene, caryophyllene, germacren and $\alpha$-selinene. Of these compounds, $\beta$-elemene, caryophyllene and $\alpha$-selinene, stood out in production in two populations, the others stood out as majorities for all accessions in relation to the percentage of the relative area of the peak.

The chemotypes identified in the present study were mircene (11) that was highlighted as majority in five accessions: (GIG 30.5\%), (RPE $14.5 \%$ ), (JFE $13.5 \%$ ), (ODA $26.9 \%$ ) and (RTI $15.3 \%$ ), linalool (22), was the majority in two accessions (PRP $18.3 \%$ ) and (SRI $33.7 \%$ ). Gomide et al (2013) recorded the mircene as majority with 18.48 $\%$, but the linalool was lower than the percentage of this study, with only $1.03 \%$ for the accession collected in Juíz de Fora (Zona da Mata). However, Leitão (2008) did not record the production of this compound in the accession collected in Diamantina (Vale Jequitinhonha). The $\alpha$-pinene (5) was the majority in SNO with $15.7 \%$ and limonene (15) in $\mathrm{ABO}(28.6 \%)$, in which the latter compound was higher than that reported by Leitão (2008) with $8.26 \%$ for the same species. Lower percentages were also obtained by hydrodistillation for Lippia thymoides Mart.; Shauer, with contents between 1.67 and $3.75 \%$ and by headspace for Lippia citriodora kunth and Lippia alba Mill. With 13.4 $\%$ and $4.7 \%$, respectively (Meshkatalsadat et al. 2010, Parra-Garcés et al. 2010).

The monoterpene, tagetone (26) $18 \%$, was detected only in SGS, being the first reported for the species. This compound was observed in Lippia javanica (Burm.f.) Spreng. at concentrations ranging from 0.3 to $4.93 \%$ (Viljoen 2005). In Lippia triplinervis Gardner, they obtained an isomeric form (Z) that also varied with seasonality, with $0.1 \%$ in April and $19.4 \%$ in September (Leitão et al. 2011). The $(Z)$ isomer has also been reported in small 
amounts in Lippia lacunosa Mart. \& Schauer with $0.5 \%$, whose species is considered synonymous of Lippia rotundifolia (Leitão 2008). The principal volatiles obtained in the present study diverged from the compounds presented by Leitão (2008), which reported myrtenal as majority compound of Lippia rotundifolia, with production of $16.7 \%$. In the analysis, this compound was recorded in small concentrations only in two accessions, (GIG 0.6 $\%$ ) and (RTI $8.8 \%$ ). Gomide et al. (2013) didn't register its production, however they obtained (E/Z) farnezol in good quantity $(16.47 \%)$, being this the second most abundant compound reported by the authors for the Juiz de Fora access, whose compound, were not recorded in any of the 11 accessions analyzed.

The chemical polymorphism in the species is confirmed by the clustering of the environments as a function of volatile production. The dendrogram by the UPGMA method grouped the accessions into three groups (Figure 1).

The first group is formed by the SRI and PVP accessions, although they have different chemical compounds, they present the highest caryophyllene production (49), (SRI $=24 \%$ and PVP $=14.1 \%$ ), whose percentages were higher than those reported in the literature for the accession of Diamantina (7.9 \%) and of Juíz de Fora (2.02 \%) (Leitão 2008, Gomide et al. 2013). Another majority compound for these two accessions was germacrene in SRI, a secondary marker with $(57=24.4 \%)$ and in PVP was the majority with $(57=21.5 \%)$. These values were considered high since they were not detected in other accesses studied (Gomide et al. 2013). The compounds $\beta$-elemene $(45=17.2 \%)$ and $\alpha$-selinene in PVP $(60=13.8 \%)$ were the secondary constituents. The $\beta$-elemene, although it was not the majority in any accession, was higher than the percentage reported in the literature for Diamantina (10.9\%) and Juíz de fora (3.45\%) accessions (Leitão 2008, Gomide et al. 2013). In addition to these characteristics, the plants of these environments were those that produced the least amount of volatile compounds $(n=5$ and 14$)$ and are the two most distant accessions geographically (Table II and Figure 1).

The second group was formed by accessions ODA, GIG, RPE, ABO, PRP, JFE and SNO. In these environments, the individuals analyzed produce the same volatiles; myrcene, limonene, $\alpha$-pinene and linalool with good representativeness. However, the JFE accession did not produce limonene and $\beta$-ocimene (15 to 17 ), and SNO did not produce germacrene (57), this being the main chemical difference observed among the seven accessions belonging to this group. The third group was formed by RTI and SGS accessions, where they grouped by chemical proximity, since both produced the main volatiles common to all environments, with limonene $(15=14.6 \%)$ as the secondary compound of RTI and linalool $(22=7.7 \%)$ as SGG secondary (Table II and Figure 1).

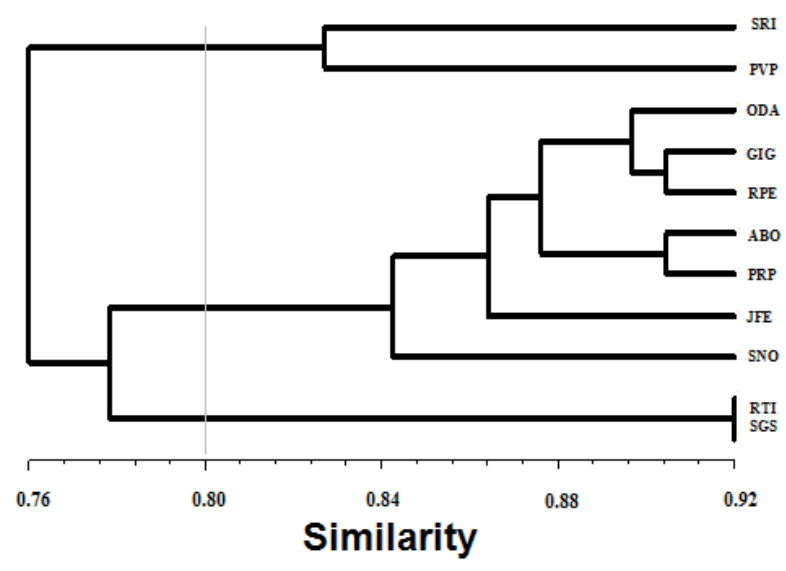

Figure 1 - Analysis of grouping by the UPGMA method of accessions of Lippia rotundifolia Cham. from eleven naturally occurring populations in Minas Gerais, Brazil. SRI: Santana do Riacho in Lapinha; PVP: Veredas do Peruaçu State Park; ODA: APA de Olhos D'água; GIG: Gigante Community in Botumirim; RPE: Rio do Peixe in Botumirim; ABO: Abóboras Community in Montes Claros; PRP: Rio Preto State Park; JFE: Serra Geral in Joaquim Felício; SNO: Serra Nova State Park; RTI: Rio Tigre in Gouveia and SGS: São Gonçalo do Rio das Pedras in the Serro district. 


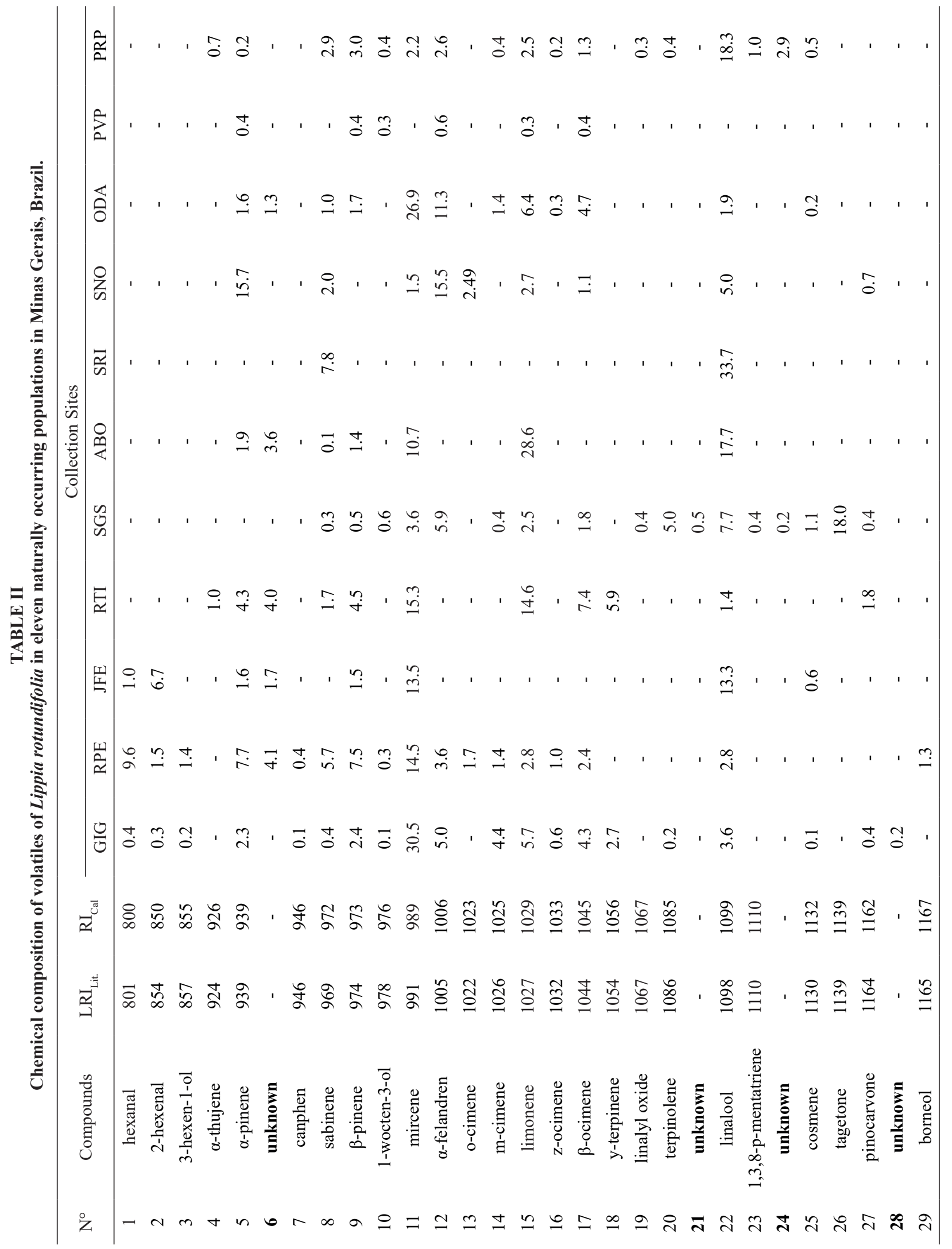




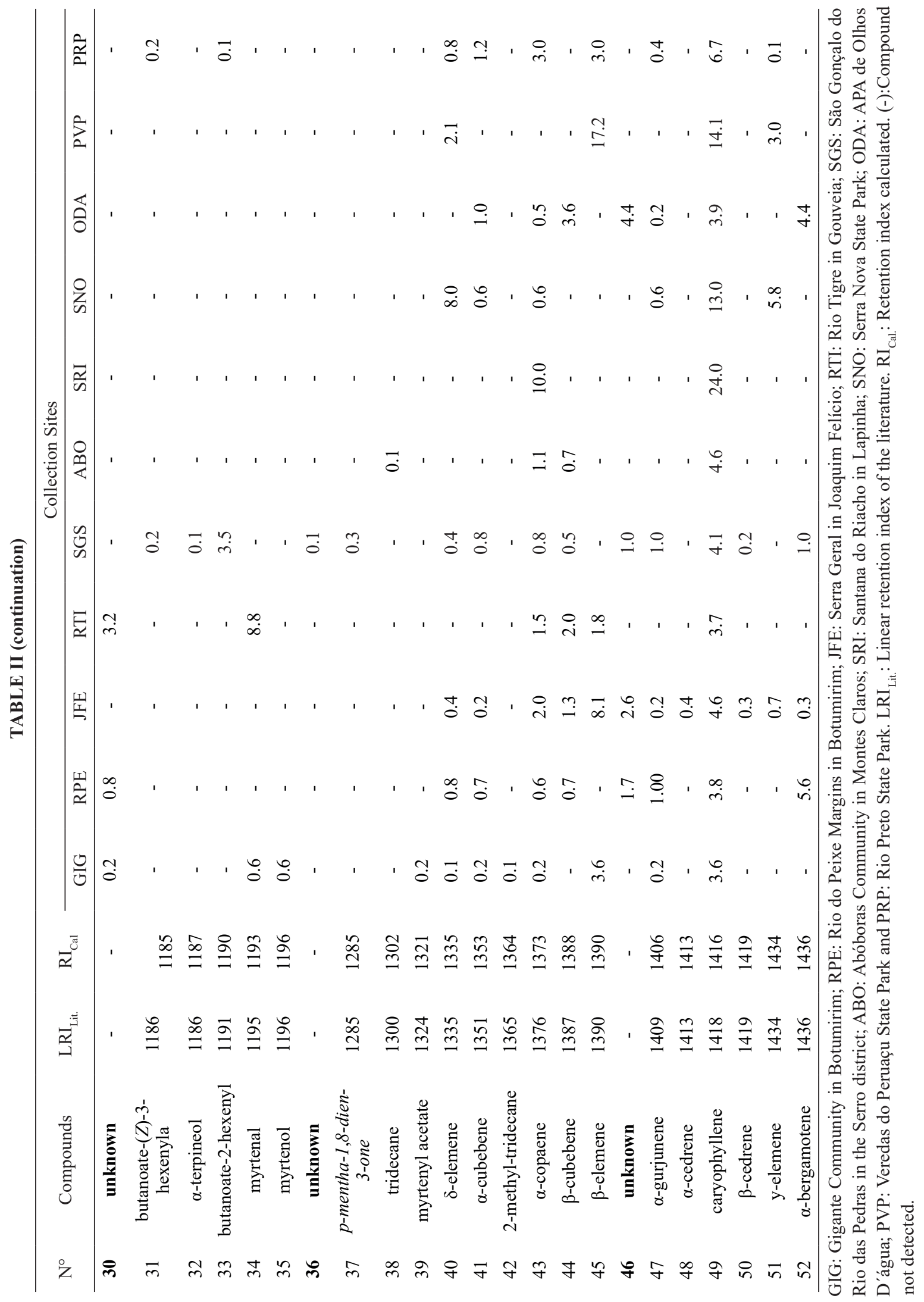


The distribution of the chemical compounds was confirmed by analysis of the principal component (PCA) of the relative area of each compound detected for the 11 accessions. This analysis summarized the chemical variables in the first two main components (PC). These were retained for interpretation, as they presented cumulative eigenvalues of $96.58 \%$ of the total variance among volatile compounds. The first component explained $90.175 \%$ of the variability for all the samples, in which it showed clear separation of the volatile attributes of the species. The second component explains only $6.405 \%$ of the total variance. The attributes with the highest factor load in the first component are presented in Table III.

The distribution of the ten most abundant volatile compounds in the two main components corroborates the their detection for the 11 accessions, in which monoterpene, tajetone (26), is the compound that is farthest from center, presenting higher standard deviation, which confirms its exclusivity in the SGS accession (Figure 2).

The graphical projection of the discriminant analysis of the 11 accessions corroborates the results presented in Table II, which it shows that the species has chemotypes belonging to the two main chemical classes. The accessions with a greater predominance of monoterpenes were grouped in the upper plane (GIG, RPE, RTI, SGS, PRP), whereas accessions with predominance of sesquiterpenes were grouped in the lower plane (JFE, ABO, SRI, ODA, PVP). This analysis also corroborates the in loco observation, in which the accessions that were farther away in the graphic dispersion of the discriminant analysis were those that produced the lowest number of volatiles $n=5$ for SRI and $n=14$ for PVP (Figure 2).

These two accessions are the most chemically and geographically distant. The small amount of volatiles produced in SRI and PVP can be explained by anthropic interference, since in PVP there was

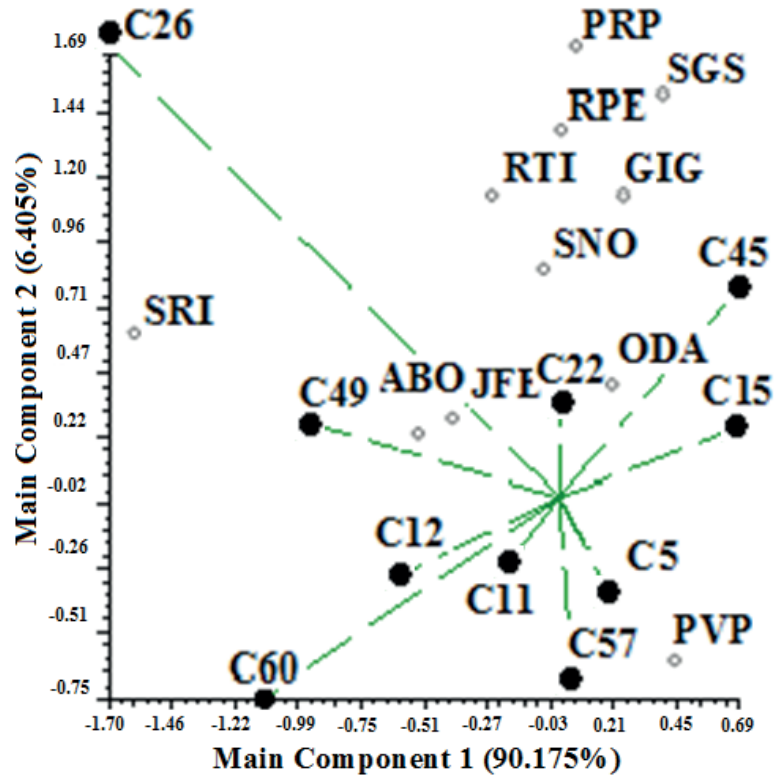

Figure 2 - Principal component analysis and two-dimensional scale dispersion of the ten major volatiles (a) of Lippia rotundifolia Cham. of 11 accessions belonging naturally occurring populations in Minas Gerais, Brazil. (5) $\alpha$-pinene; (11) myrcene; (12) $\alpha$-felandrene; (15) limonene; (22) linalool; (26) tagetone; (45) $\beta$ - elemene; (49) caryophyllene; (57) germacrene; (60) $\alpha$-selinene. SRI: Santana do Riacho in Lapinha; PVP: Veredas do Peruaçu State Park; ODA: APA Olhos D'água; GIG: Gigante Community in Botumirim; RPE: Rio do Peixe in Botumirim; ABO: Abóboras Community in Montes Claros; PRP: Rio Preto State Park; JFE: Serra Geral in Joaquim Felício; SNO: Serra Nova State Park; RTI: Rio Tigre in Gouveia and SGS: São Gonçalo do Rio das Pedras in the Serro district.

occurrence of fires, while in SRI, although the environment is close to a water course, suitable for the establishment of the species, there was the presence of domestic animals foraging on the site. In these two environments, individuals presented leathery leaves with no apparent odor. These observations evidence the phytochemical and morphological differences of the individuals in response to the environmental conditions to which they are exposed (Osorno-Sanchez et al. 2012, Calvo-Irabién et al. 2014).

The variation in the chemical profile is also explained by the genetic interaction with the environment, since the secondary metabolites are genetically controlled, probably polygenic, and 
TABLE III

Chemical attributes of volatiles of Lippia rotundifolia with the eigenvalues of the main components from the eleven naturally occurring populations in Minas Gerais, Brazil.

\begin{tabular}{lccc}
\hline & Components of variance & \multicolumn{2}{c}{ Volatile compound index } \\
\cline { 2 - 4 } & & CP1 & CP2 \\
\hline & Variability (\%) & 90.175 & 6.405 \\
\multicolumn{2}{c}{ Accumulated variability (\%) } & 90.175 & 96.58 \\
\hline 15 & Variables & & Factorial load (Scores) \\
49 & limonene & 0.987 & 0.024 \\
57 & caryophyllene & 0.959 & 0.167 \\
22 & germacrene & 0.959 & 0.189 \\
26 & $\beta$-linalool & 0.998 & 0.016 \\
12 & tagetone & 0.978 & 0.025 \\
45 & $\alpha$ - felandren & 0.941 & 0.003 \\
59 & $\beta$-elemene & 0.949 & 0.014 \\
48 & eremophilene & 0.659 & 0.105 \\
\hline
\end{tabular}

are associated with the plant defense mechanism, in which it causes significant alterations to the chemical composition of the volatiles. Thus, environmental conditions may influence the expression of the gene responsible for the activation of the terpene synthase enzymes involved in the biosynthesis of terpene volatiles (Pinto-Zevallos et al. 2013, Winska et al. 2014, Pavarini and Lopes 2016).

In order to conserve native aromatic plants with economic potential, the first step is to identify the best adapted genotypes and, from these, to work on their genetic improvement in order to standardize the crop to meet the market demand. Within this idea, the influence of the environment on the variation of the chemical profile of Lippia rotundifolia, is a positive characteristic as a survival mechanism. This factor also shows the potential of the species to be explored in the natural products market, since each environment expresses the genes responsible for the production of a certain chemical compound, which can be a source of income for the region in which it occurs (Yamamoto et al. 2008, Winska et al. 2014).
From the results presented, the highest number of compounds was obtained in SGS $(n=40)$, GIG $(\mathrm{n}=38)$ and PRP $(\mathrm{n}=35)$ and the lowest number of compounds was obtained in SRI $(n=5)$ and PVP N =14). However, within the chemical polymorphism presented by the species, it is proposed that the chemical variation of the species is distributed in six potential chemotypes which are attributed by the volatiles myrcene, linalool, $\alpha$-pinene, limonene, tagetone and germacrene, whose chemical compounds are the most abundant for the species in Minas Gerais. However, studies of molecular analysis are necessary for support this hypothesis.

\section{CONCLUSIONS}

Lippia rotundifolia presents high chemical variability. The SGS accession has the highest number of chemical compounds and SRI accession has smaller number. PVP accession holds the greatest chemical distance. The volatiles mircene, linalool and caryophyllene are the most frequent, detected in most of the accessions. Due to some accession to present predominance of monoterpenes, others sesquiterpenes, studies of 
molecular analysis are necessary for associate the chemotypes, since environmental variation influence the gene expression of the secondary metabolites.

\section{ACKNOWLEDGMENTS}

The authors thanks Coordenação de Aperfeiçoamento de Pessoal de Nível Superior (CAPES), Conselho Nacional de Desenvolvimento Científico e Tecnológico (CNPq) and FAPEMIG for financial support and the colleagues Ane Patrícia Cacique and Érica Soares Barbosa and the teacher Flaviano Oliveira Silvério of Agrochemical Research Laboratory of ICA - UFMG for technical support.

\section{AUTHOR CONTRIBUTIONS}

First author: chapter thesis of Doctorate; Second author: research coordinator; Third author: Chemical Technique responsible for chemical analysis.

\section{REFERENCES}

CALVO-IRABIÉN LM, PARRA-TABLA V, ACOSTAARRIOLA V, ESCALANTE- EROSA F, DÍAZ-VERA L, DZIB GR AND PEÑA-RODRÍGUEZ LM. 2014. Phytochemical Diversity of the Essential Oils of Mexican Oregano (Lippia graveolens KUNTH) Populations along an Edapho-Climatic Gradient. Chem Biodivers 11: 10101021.

CARVALHO F, DE SOUZA FA, CARRENHO R, MOREIRA FMS, JESUS ED AND FERNANDES GW. 2012. The mosaico of habitats in the high-altitude Brazilian rupestrian fields is a hotspot from arbuscular mycorrizal fungi. Appl Soil Ecol 52: 9-19.

COUNCIL OF EUROPE EUROPEAN PHARMACOPOEIA. 2010. European Directorate for the Quality of Medicines, $7^{\text {th }}$ ed., Strasbourg: France, 241 p.

FERNANDES GW, OKI YUMI, SANCHEZ-AZOFEIFA A, FACCION G AND AMARO ARRUDA HC. 2011. Hail impact on leaves and endophytes of the endemic threatened. Coccoloba cereifera (Polygonaceae). Plant Ecol 212: 1687-1697.

GASTAUER M, MESSIAS MCB AND NETO JAM. 2012. Floristica composition, Species Richness and Diversity of Rocky fields Vegetation from the Itacolomi State Park, Minas Gerais, Brazil. Environ Nat Resource Res 2: 115130.

GOMIDE MS, LEMOS FO, LOPES MTP, ALVES, TMA, VICCINI LF AND COELHO CM. 2013. The effect of the essential oils from Five different Lippia species on the viability of tumor cell lines. Rev Bras Farmacog 23: 895-902.

JACOBI CM, DO CARMO FF AND DE CAMPOS IC. 2011. Soaring extinction threats to endemic plants in Brazilian metal-rich regions. Ambio 40: 540-543.

LEITÃO SG, 2008. Analysis of the Chemical Composition of the Essential Oils Extracted from Lippia lacunosa Mart. e Schauer and Lippia rotundifolia Cham. (Verbenaceae) by Gas Chromatography and Gas Chromatography-Mass Spectrometry. J Braz Chem Soc 19: 1388- 1393.

LEITÃO SG, DAMASCENO JPL, MARTINI MG, MIRANDA SN AND NEUFELD P. 2011. Analysis of the chemical composition and antimicrobial activity of the essential oil from Lippia triplinervis Gardner (Verbenacea). J Essent Oil Res 23: 20-24.

MARTENS LA. 2008. Flores da Serra da Calçada, UFMG: Belo Horizonte, $478 \mathrm{p}$.

MESHKATALSADAT MH, PAPZANAHAND ABDOLLAHI A. 2010. Determination of bioactive volatile organic components of Lippia citriodora using ultrasonic assisted with headspace solid phase microextraction coupled with GC-MS. Dig J Nanomater Biostruct 6: 319-323.

NIST. 2008. Standard Reference Database 69: NIST Chemistry Web Book.

OSORNO-SÁNCHEZ TG, TORRES RUIZ A AND LINDIGCISNEROS R. 2012. Effects of harvesting intensity on population structure of Lippia graveolens (Verbenaceae, Lamiales) in the Semidesert of Queretaro. Afr J Agric Res 7: 100-108.

PARRA-GARCÉS MI, CAROPRESE-ARAQUE JF, ARRIETA-PRIETO D AND STASHENKO E. 2010. Morfología, anatomia, ontogenia y composición química de metabolitos secundários em influrescencias de Lippia alba (Verbenaceae). Rev Biol Trop 58: 1533-1548.

PAVARINI DP AND LOPES NP. 2016. Ecologia química e a biossíntese dos terpenos voláteis das Arnicas-da-Serra (Lychnophora spp.). RVQ 8: 242-262.

PINTO-ZEVALLOS DM, MARTINS CBC, PELLEGRINO AC AND ZARBIN PHG. 2013. Compostos orgânicos voláteis na defesa induzida das plantas contra insetos herbívoros. Quím Nova 36: 1395-1405.

RAPINI A, RIBEIRO P, LAMBERT S AND PIRANI JR. 2008. A flora dos campos rupestres da Cadeia do Espinhaço. Megadiversidade 4: 1-2.

ROHLF FJ. 2000. Numerical taxonomy and multivariate analysis system, version 2.11. New York: applied Biostatistics, Exeter Software. 
SALIMENA FR AND SILVA TRS. 2009. Flora de GrãoMogol, Minas Gerais, Verbenaceae. Bol Bot 27: 119-120.

SALIMENA FRG AND MÚLGURA ME. 2015. Notas taxonômicas em Verbenanceae do Brasil. Rodriguésia 66: 191-197.

STASHENKO EE, PUERTAS MA AND MARTÍNEZ JR. 2002. SPME determination of volatile aldehydes for evaluation of in-vitro antioxidant activity. Anal Bioanal Chem 373: 70-74.

VAN DEN DOOL H AND KRATZ PD. 1963. A generalization of the Retention Index System Including Linear Temperature Programmed Gas- Liquid Partition Chromatography. J Chromatogr A, 11: 463- 471.
VILJOEN AM. 2005. The composition, geographical variation and antimicrobial activity of Lippia javanica (Verbenaceae) leaf essential oils. J Ethnopharmacol 96: 271-277.

WINSKA K, POTANIEC B, MACZKA W, GRABARCZYK M, ANIOL M AND WAWRZENCZYK C. 2014. Isomers and odor or nose as stereochemist. Chemik 68: 83-90.

YAMAMOTO PV, COLOMBO CA, AZEVEDO FILHO JÁ, LOURENÇÃO AL, MARQUES MOM, MORAIS GDS, CHIORATO AF, MARTINS ALM AND SIQUEIRA WJ. 2008. Performance of ginger Grass (Lippia alba) for traits related to the production of essencial oil. Sci Agric 65: 481-489. 